\title{
Trifluoromethylation of carbonyl groups in aromatic poly(ether ketone)s: formation of strongly polar yet surface-hydrophobic poly(arylenenecarbinol)s
}

Article

Accepted Version

Leroux, F., Bennett, R., Lewis, D. and Colquhoun, H. M. (2018) Trifluoromethylation of carbonyl groups in aromatic poly(ether ketone)s: formation of strongly polar yet surface-hydrophobic poly(arylenenecarbinol)s. Macromolecules, 51 (9). pp. 34153422. ISSN 0024-9297 doi:

https://doi.org/10.1021/acs.macromol.8b00017 Available at https://centaur.reading.ac.uk/77256/

It is advisable to refer to the publisher's version if you intend to cite from the work. See Guidance on citing.

Published version at: https://pubs.acs.org/doi/10.1021/acs.macromol.8b00017

To link to this article DOI: http://dx.doi.org/10.1021/acs.macromol.8b00017

Publisher: American Chemical Society

All outputs in CentAUR are protected by Intellectual Property Rights law, including copyright law. Copyright and IPR is retained by the creators or other copyright holders. Terms and conditions for use of this material are defined in the End User Agreement. 


\section{www.reading.ac.uk/centaur}

\section{CentAUR}

Central Archive at the University of Reading

Reading's research outputs online 


\section{Trifluoromethylation of carbonyl groups in aromatic poly(ether ketone)s: formation of strongly polar yet surface-hydrophobic poly(arylenenecarbinol)s}

Flavien Leroux, Roger A. Bennett, David F. Lewis and Howard M. Colquhoun*

Department of Chemistry, University of Reading, Whiteknights, Reading, RG6 6AD, UK

Abstract: Fluoride-catalyzed reactions of trimethyl(trifluoromethyl)silane with a range of aromatic poly(ether ketone)s, both amorphous and semi-crystalline, proceed quantitatively in THF to yield soluble, amorphous polymers in which the carbon-silicon bond of $\mathrm{CF}_{3} \mathrm{SiMe}_{3}$ has added across the carbonyl-oxygen double bond of each carbonyl group. When the starting poly(ether ketone) is amorphous and soluble in THF the reaction is fairly rapid (hours), but is much slower (days) when the starting polymer is semi-crystalline, with only low solubility in THF. Quantitative desilylation of the resulting polymers is achieved by reaction with excess fluoride ion, affording poly(arylene-trifluoromethylcarbinol)s. These extremely polar polymers are readily soluble in protic solvents such as methanol or ethanol, to give solutions from which tough, coherent films may be cast by evaporation in air. Despite the evidently high polarity of the bulk polymers, the surfaces of cast films are relatively hydrophobic, with static water contact angles of $\sim 90^{\circ}$. Surface analyses by XPS are consistent with enrichment of the polymer-air interface in $\mathrm{CF}_{3}$ groups. 


\section{Introduction}

Semicrystalline aromatic poly(ether ketone)s represent an industrially-important class of highperformance thermoplastics with outstanding physico-chemical properties. ${ }^{1}$ For example, PEEK (Chart 1) is widely used in situations that require mechanical strength at very high temperatures, ${ }^{2}$ or in chemically aggressive environments, ${ }^{3}$ or in applications such as medical implants and prostheses which exploit its inert character and biocompatibility. ${ }^{4}$ It also finds increasing application as a thermoplastic matrix in high-performance carbon fibre composites. ${ }^{5}$
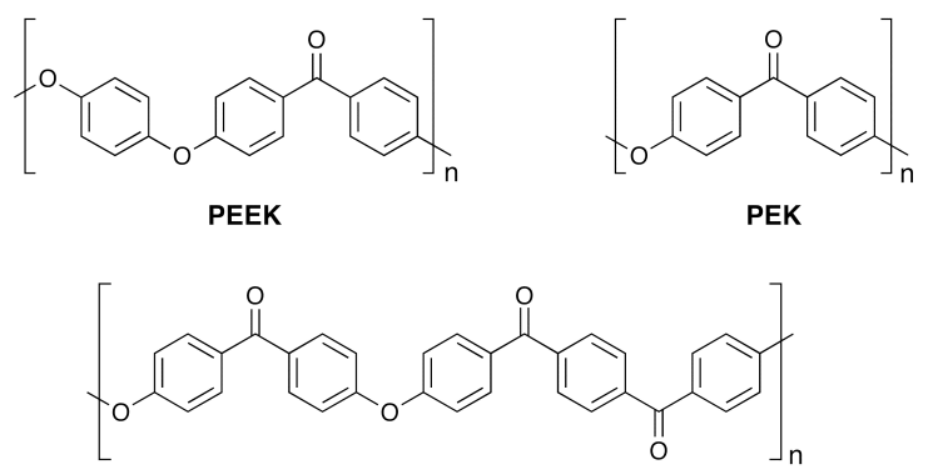

PEKEKK

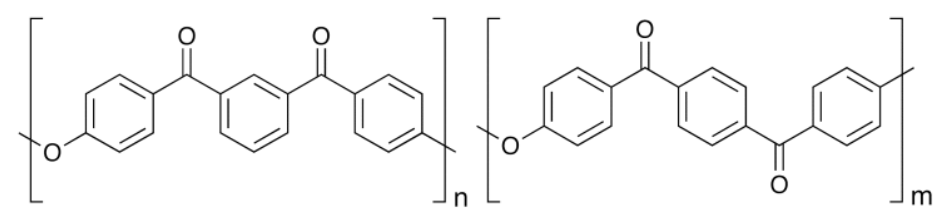

PEKK (family of 1,3/1,4-copolyketones)

Chart 1. Some industrially important poly(aryl ether ketone)s

Several post-synthesis derivatization reactions of semi-crystalline poly(ether ketone)s have been described, though the insolubility of the latter in conventional solvents precludes the application of many types of chemistry. ${ }^{6}$ Nevertheless, PEEK may be sulfonated selectively at the hydroquinone residue simply by dissolving it in concentrated sulfuric acid. ${ }^{7}$ The resulting 
polysulfonate ionomer (depending on the degree of sulfonation) may then be soluble in polar aprotic solvents such as $N, N$-dimethylformamide or $N, N$-dimethylacetamide. ${ }^{7}$ However, this type of chemistry is far from general in that many important poly(ether ketone)s such as PEK, PEKEKK and PEKK (Chart 1), in which every ring carries at least one deactivating carbonyl group, dissolve in but are essentially inert to concentrated (96-98\%) sulfuric acid. ${ }^{8}$ Nitration of PEEK (again occurring at the hydroquinone residue) has been achieved both homogeneously in strong acid solution, ${ }^{9}$ and also in suspension in so-called mixed acid (4:1 v/v nitric:sulfuric). ${ }^{10}$ Other derivatization chemistries involve reactions at the carbonyl groups, for example reduction by triethylsilane and strong acid to yield poly(ether methylene)s, ${ }^{11}$ reduction with sodium borohydride to give poly(carbinol)s, ${ }^{12}$ iminization with high-boiling primary amines, ${ }^{13}$ and perhaps most successfully the reversible formation of poly(dithioketal)s by reaction with aliphatic dithiols in the presence of a Lewis acid..$^{14,15}$

The insolubility of semi-crystalline poly(ether ketone)s in conventional organic solvents has also allowed the development of a wide range of surface-derivatized materials. Such reactions include reduction with borohydride to yield surface-hydroxylated PEEK, ${ }^{16}$ which may be further functionalised by ATRP to graft hydrophilic poly(ethyleneglycol) methacrylate chains onto the surface. ${ }^{17}$ Most recently it has been reported that PEEK may be surface-fluorinated by a proceess involving argon plasma treatment followed by contact with aqueous HF. ${ }^{18}$ The resulting polymer showed enhanced antibacterial properties and improved compatibility with stem cells, but the nature of the surface chemistry involved in this type of fluorination was not established.

Here we report the exploration of a novel, fully-defined approach to the introduction of fluorinated groups into aromatic poly(ether ketone)s by a process involving the quantitative addition of trifluoromethyl(trimethyl)silane ${ }^{19}$ to the carbonyl groups. ${ }^{20}$ This nucleophilic 
trifluoromethylation reaction (Scheme 1) is well-established in small-molecule chemistry, ${ }^{21}$ but has not been applied previously to the functionalization of macromolecules.

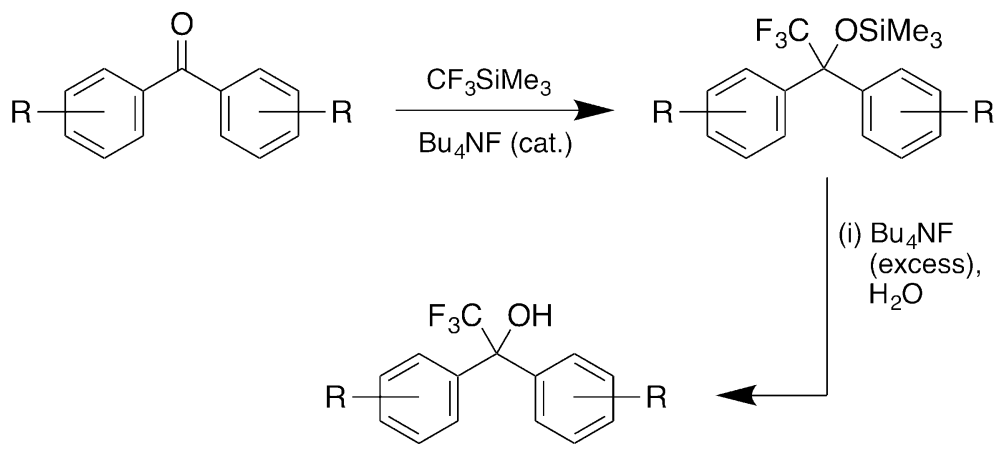

Scheme 1. Conversion of an aromatic ketone to a trifluoromethylcarbinol via the trimethylsilylether derivative, by fluoride-catalyzed addition of $\mathrm{CF}_{3} \mathrm{SiMe}_{3}$ to the carbonyl group. ${ }^{20,21}$

It is well-established that fluorocarbon moieties in polymeric systems tend to segregate at the polymer-air interface, giving rise to low-energy, hydrophobic surfaces. ${ }^{22}$ Such systems include poly(perfluoroalkyl methacrylate) homopolymers and copolymers, ${ }^{23,24}$ di-and tri-block copolymers containing one highly fluorinated block, ${ }^{25,26}$ anionically-polymerised polyalkenes such as polystyrene or polybutadiene terminated with a single, short (e.g. $\left.-\mathrm{C}_{8} \mathrm{~F}_{17}\right)$ perfluoroalkyl chain, ${ }^{27,28}$ and fluorocarbon-grafted polymers such as those formed by difluorocarbene addition to the double bonds of poly(isoprene). ${ }^{29,30}$ The vast majority of these previously-reported systems combine fluorocarbon residues with subunits that are themselves relatively hydrophobic (typically having hydrocarbon, ester or ether functionality). In contrast, the new materials reported here introduce both a strongly hydrophilic hydroxyl group and a strongly hydrophobic trifluoromethyl group at the same backbone carbon atom(s) in every polymer repeat unit, leading to polymers with some unusual physico-chemical characteristics. 


\section{Results and discussion}

Our initial attempts to apply nucleophilic trifluoromethylation chemistry to highly crystalline and insoluble poly(ether ketone)s such as PEEK and PEK (Chart 1) in suspension in THF failed to afford any reaction, even with very finely-divided polymer powders $(<50 \mu \mathrm{m})$. We next investigated a series of THF-soluble or -swellable, poly(ether ketone)s (1-4, Chart 2) that were synthesised at high molecular weight from monomers 5-9 using conventional polyetherification chemistry. ${ }^{31}$ These polymers were designed to provide widely different ketone contents and thus, potentially, to afford fluorinated polyols with a range of equivalent weights in terms of trifluoromethylcarbinol units. Polymers $\mathbf{1}$ and $\mathbf{2}$ are known to be amorphous, ${ }^{32}$ and although polymer 4 is semi-crystalline, it has a relatively low melting point $\left(310{ }^{\circ} \mathrm{C}\right)^{33}$ and was thus predicted to be more soluble and reactive than PEEK or PEK. Neither monomer $\mathbf{8}$ nor polymer $\mathbf{3}$ (which also proved to be amorphous) have been reported previously, but the discovery in this work of a novel "extended Fries" rearrangement (Scheme 2) allowed monomer $\mathbf{8}$ to be obtained in good yield and purity. Polymers 1-4 were synthesised by polycondensation at high temperature in either NMP or diphenylsulfone as solvent, as described in the Supporting Information (SI) where full characterisation data are also given.

Polyketones $\mathbf{1}$ and $\mathbf{2}$ were fully soluble in THF and reacted cleanly with trifluoromethyl(trimethyl)silane) in the presence of catalytic amounts of tetra- $n$-butylammonium fluoride to afford, after $18 \mathrm{~h}$, the trifluoromethylated polymers $\mathbf{1 0}$ and $\mathbf{1 1}$ in $82 \%$ and $70 \%$ yields respectively (Chart 3). Polymers 3 and $\mathbf{4}$ did not dissolve in THF, though the amorphous, dibenzofuran-based polymer $\mathbf{3}$ swelled significantly in this solvent. Nevertheless, it was found that 3 and 4 could be succesfully trifluoromethylated over a much longer period (120 h) by 
repeated addition of $\mathrm{CF}_{3} \mathrm{Si}\left(\mathrm{CH}_{3}\right)_{3}$ and $\mathrm{Bu} 4 \mathrm{NF}$ at $24 \mathrm{~h}$ intervals, ultimately giving polymers 12 and $\mathbf{1 3}$ in $80 \%$ and $75 \%$ yields respectively (Chart 3 ).

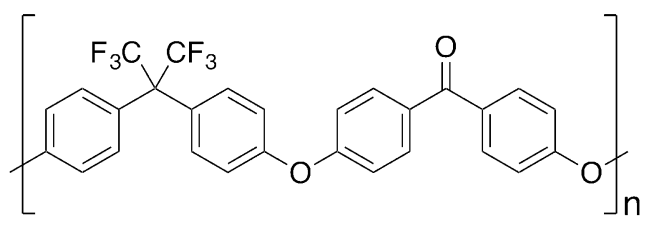

1<smiles>CCCOc1ccc(C(=O)c2ccc3oc4ccc(C(=O)c5ccc(C)cc5)cc4c3c2)cc1</smiles>

3<smiles>O=C(c1ccc(F)cc1)c1ccc(F)cc1</smiles>

5<smiles>O=C(c1ccc(O)cc1)c1ccc2oc3ccc(C(=O)c4ccc(F)cc4)cc3c2c1</smiles>

8<smiles>Cc1ccc(C(c2ccc(Oc3ccc(C(=O)c4cccc(C(=O)c5ccc(OCC(C)C)cc5)c4)cc3)cc2)(C(F)(F)F)C(F)(F)F)cc1</smiles>

2<smiles>COc1ccc(C(=O)c2cccc(C(=O)c3ccc(C)cc3)c2)cc1</smiles>

4<smiles>Oc1ccc(C(c2ccc(O)cc2)(C(F)(F)F)C(F)(F)F)cc1</smiles>

7

9

Chart 2. Poly(arylene ether ketone)s 1-4, synthesised in the present work using monomers 5-9.

All four trimethylsilyl polymers, 10-13, proved readily soluble in THF, and subsequent GPC analyses in this solvent showed number average molecular weights $M_{\mathrm{n}}$ in the range $15-59 \mathrm{kDa}$, with dispersities between 1.9 and 2.9. Full characterization details are given in the SI. 


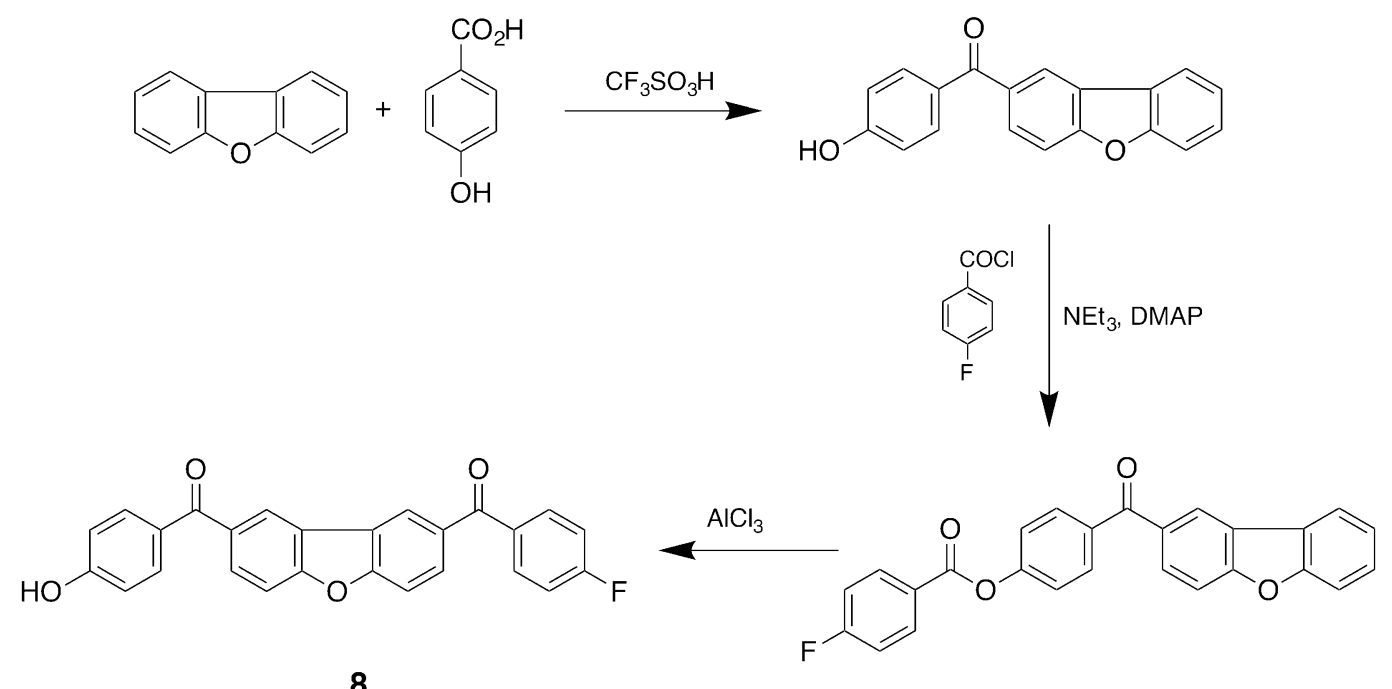

8

Scheme 2. Synthesis of monomer 8 from dibenzofuran via sequential hydroxybenzoylation, esterification and "extended-Fries" rearrangement of the ester in triflic acid. Like the standard Fries "rearrangment", the latter is almost certainly a bimolecular Friedel-Crafts type reaction in which an oxyaryl group (here the dibenzofuran residue) of one ester molecule is aroylated by a second molecule of the ester.

An intriguing feature of the ${ }^{1} \mathrm{H}$ NMR spectra of both isophthaloyl-derived polymers $\mathbf{1 1}$ and $\mathbf{1 3}$ is that the aromatic proton lying between the two trifluoromethylated carbons gives rise to two resonances of similar (but not equal) intensity (Figure 1). These resonances arise from the stereochemistries of the two adjacent $\left[\mathrm{Ar}\left(\mathrm{Ar}^{\prime}\right) \mathrm{C}\left(\mathrm{CF}_{3}\right) \mathrm{OSiMe}_{3}\right]$ groups which, being chiral, may combine as RS, SR, SS, or RR. The polymer repeat unit is thus diastereomeric, and the two observed ${ }^{1} \mathrm{H}$ resonances in the spectra of $\mathbf{1 1}$ and $\mathbf{1 3}$ result from magnetic inequivalence of the pairs of enantiomeric stereocentres RS/SR and RR/SS (Figure 2). Since diastereomers have different free energies of formation, the inequality of the two populations, as indicated by NMR (Figure 1), is not unexpected. Indeed, molecular mechanics calculations on model compounds suggest that, of the two enantiomeric pairs, the RS/SR diastereomeric pair is some $10 \%$ lower in energy than its SS/RR counterpart, a value that is compatible with the observed difference in intensity between the corresponding ${ }^{1} \mathrm{H}$ NMR resonances. See SI for details of these calculations. 


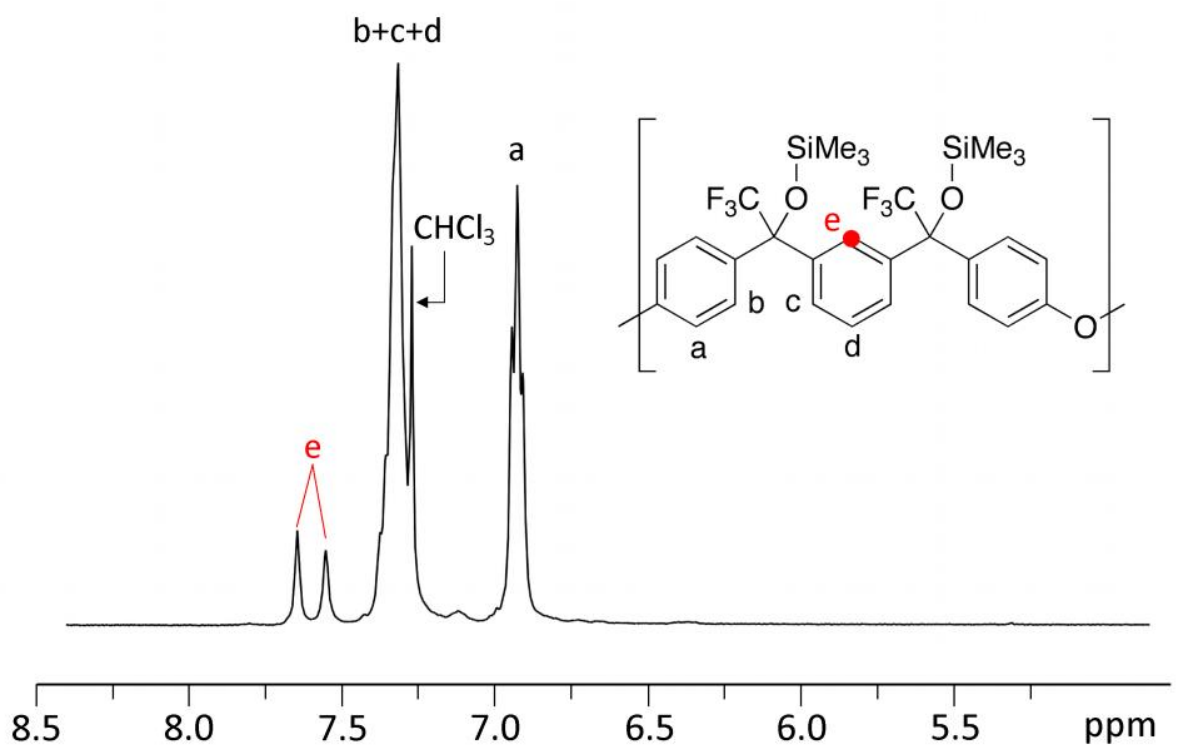

Figure 1. ${ }^{1} \mathrm{H}$ NMR spectrum of polymer $\mathbf{1 3}$ in the aromatic region, showing the two resonances arising from the single aromatic proton (e) adjacent to both trifluoromethylated carbons.

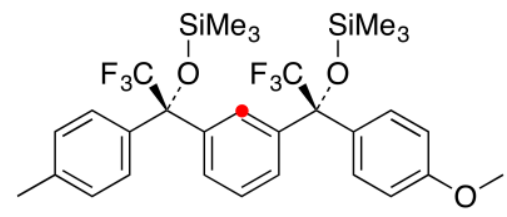

$S R$

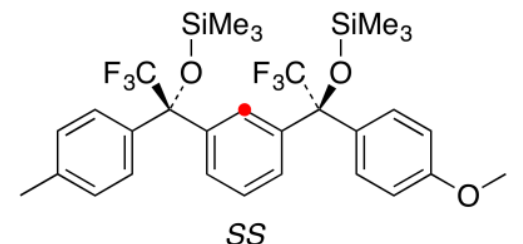

SS

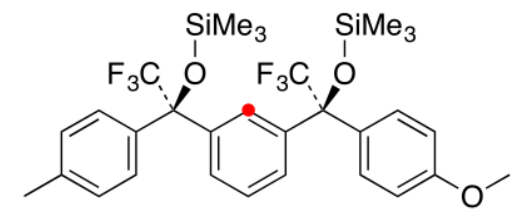

RS

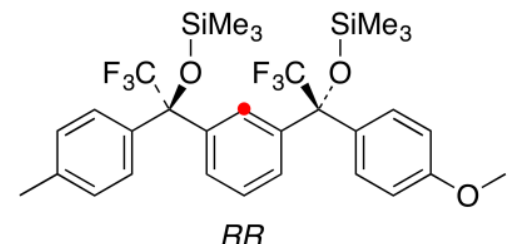

$R R$

Figure 2. Diastereomeric pairs of chiral units in polymers $\mathbf{1 1}$ and $\mathbf{1 3 .}$

Desilylation of polymers 10-13 was achieved by reaction with a large molar excess of tetra- $n$ butylammonium fluoride hydrate in THF, and the resulting trifluoromethyl polyols $\mathbf{1 4 - 1 7}$ were purified by reprecipitation in water from acetone solution and isolated in $50-75 \%$ yields. The ${ }^{1} \mathrm{H}$ NMR spectrum of polymer $\mathbf{1 5}$ is shown in Figure 3, which again shows diastereomeric effects 
in the splitting of the resonance due to the proton (g) located between the two trifluoromethylated carbons. The remarkably high resolution of this spectrum (for a high molecular weight polymer) enables all seven different proton environments in the polymer to be assigned as shown (see also SI). This spectrum also demonstrates the effectiveness of the chemistry in providing a clean, 2 -step, conversion of the starting polyketone $\mathbf{2}$ to the fully trifluoromethylated polyol 15.

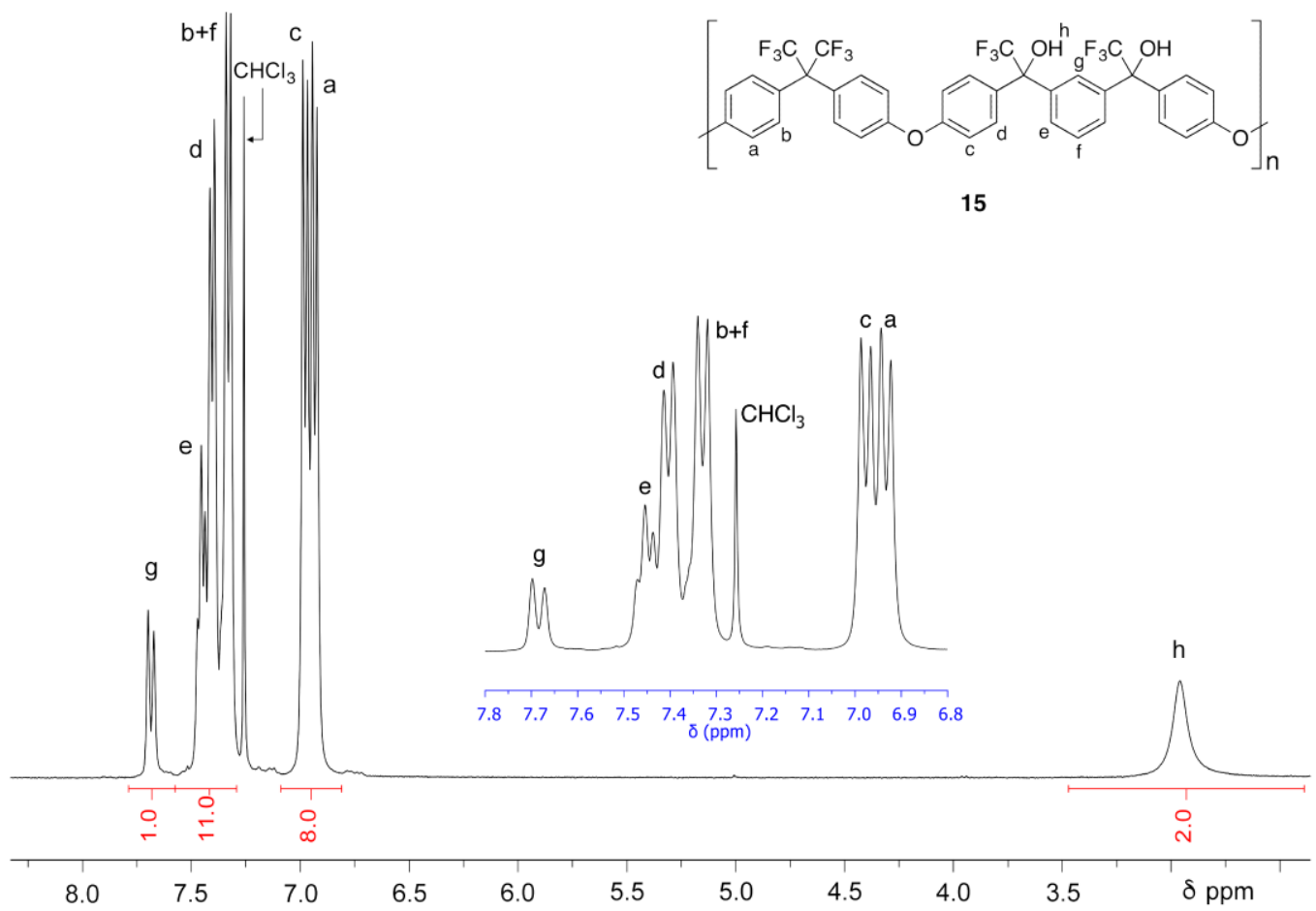

Figure 3. ${ }^{1} \mathrm{H}$ NMR spectrum of polymer 15 in $\mathrm{CDCl}_{3}$, showing the two diastereomer-related resonances arising from the single proton $(\mathrm{g})$ adjacent to both trifluoromethylated carbons, and also a complete assignment of all other resonances. Inset shows an expansion of the aromatic region. See also SI.

The structures of polyols $\mathbf{1 4}$ and $\mathbf{1 5}$ were confirmed by ${ }^{19} \mathrm{~F}$ NMR spectroscopy, which showed resonances corresponding to both the hexafluoroisopropylidene $(-64.1 \mathrm{ppm})$ and trifluoromethylcarbinol $(-74.5 \mathrm{ppm})$ groups. As show in the SI, the relative integrals of these 
two resonances correspond very closely to the ratios expected $(2: 1$ and $1: 1)$ from the structures of polymers 14 and 15 respectively, shown in Chart 3.

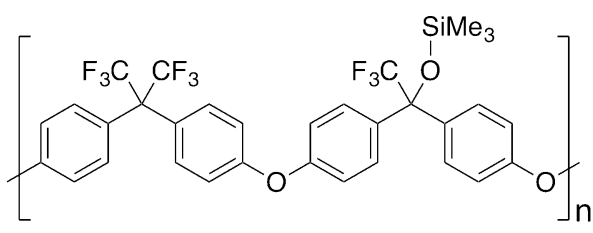

10

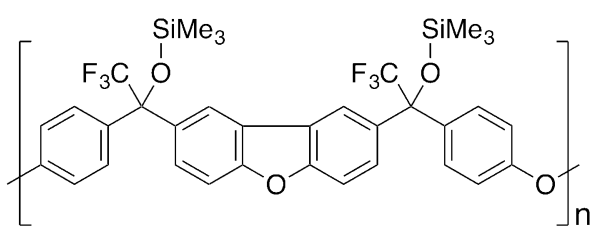

12

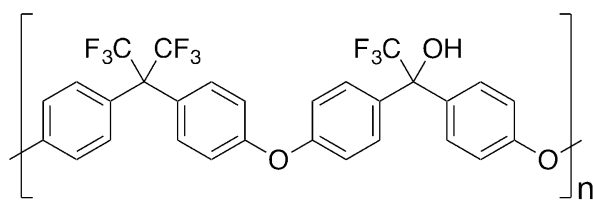

14

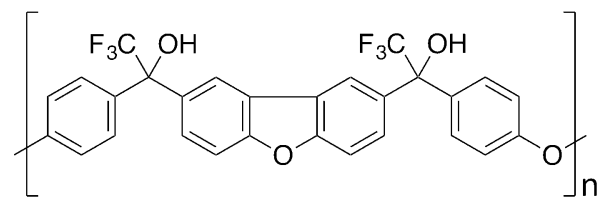

16

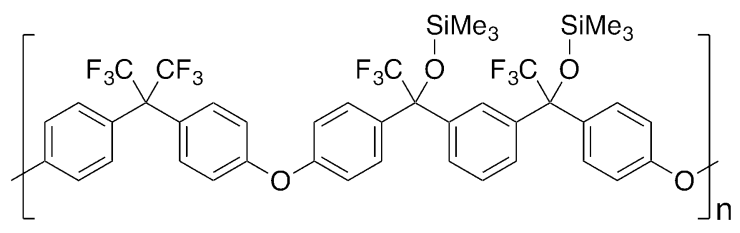

11

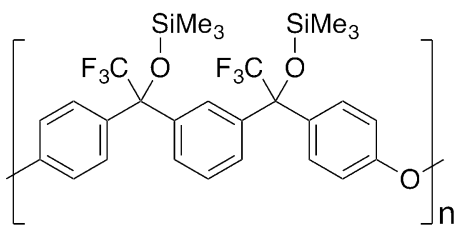

13

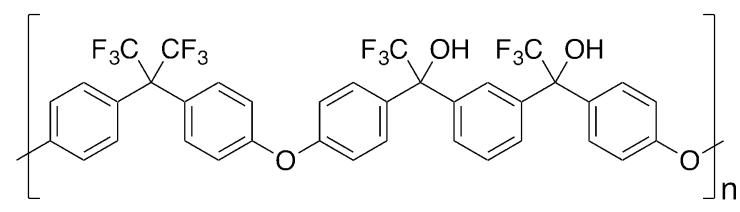

15

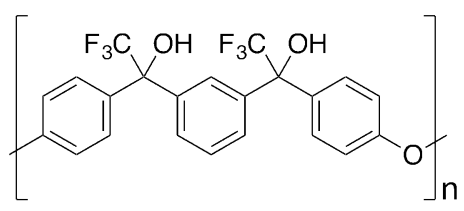

17

Chart 3. Polymers 10-13 resulting from addition of $\mathrm{CF}_{3} \mathrm{SiMe}_{3}$ to the carbonyl groups of poly(ether ketone)s 1-4, and the polycarbinols 14-17 subsequently obtained by desilylation of 10-13.

Fluoride-promoted desilylation of polymers 10-13 does not lead to degradation of the polymer backbone, as can be seen from the GPC data in Table 1 . Indeed, $\mathrm{M}_{\mathrm{w}}$ and $Ð$ values found for the desilylated polymers $\mathbf{1 5}, \mathbf{1 6}$ and $\mathbf{1 7}$ are considerable greater than those of the parent silylated 
polymers, with the effect being most striking for polyols $\mathbf{1 5}$ and 17. The GPC curve for polyol 15 is given in Figure 4, from which it is clear that there are no obvious features such as a bimodal distribution or a distorting shoulder that might account for the anomalously high molecular weight values. The origin of this result is at present unknown, though it may be significant that polyols $\mathbf{1 5}$ and $\mathbf{1 7}$ are both derived from polyketones based on the isophthaloyl unit. Preliminary computational modelling studies suggest that the MW anomalies could result from inter-chain association involving specific hydrogen bonds between 1,3-related trifluoromethylcarbinol groups, and more extensive investigations of this phenomenon are currently in progress.

Table 1. Characterisation data for polymers 1-4 and 10-17

\begin{tabular}{|l|l|l|l|l|}
\hline Polymer & $\eta_{\text {inh }}\left(\mathrm{dL} \mathrm{g}^{-1}\right)$ & $\mathrm{M}_{\mathrm{n}} / \mathrm{M}_{\mathrm{w}}(\mathrm{kDa})^{\mathrm{c}}$ & Dispersity $\Theta$ & $\mathrm{T}_{\mathrm{g}} / \mathrm{T}_{\mathrm{m}}\left({ }^{\circ} \mathrm{C}\right)^{\mathrm{e}}$ \\
\hline $\mathbf{1}$ & $0.39^{\mathrm{a}}$ & $13.0 / 23.6$ & 1.97 & $155 /-$ \\
\hline $\mathbf{2}$ & $0.74^{\mathrm{a}}$ & $20.4 / 57.00$ & 2.80 & $158 /-$ \\
\hline $\mathbf{3}$ & $0.64^{\mathrm{b}}$ & $\mathrm{d}$ & $\mathrm{d}$ & $226 /-$ \\
\hline $\mathbf{4}$ & $1.13^{\mathrm{b}}$ & $\mathrm{d}$ & $\mathrm{d}$ & $160 / 258$ \\
\hline $\mathbf{1 0}$ & - & $21.1 / 48.8$ & 2.32 & $152 /-$ \\
\hline $\mathbf{1 1}$ & - & $59.0 / 136$ & 2.31 & $127 /-$ \\
\hline 12 & - & $15.4 / 44.0$ & 2.86 & $172 /-$ \\
\hline 13 & - & $21.2 / 39.6$ & 1.87 & $90 /-$ \\
\hline 14 & - & $15.4 / 29.8$ & 1.94 & $155 /-$ \\
\hline 15 & - & $420 / 1,640$ & 3.90 & $143 /-$ \\
\hline 16 & - & $23.1 / 86.6$ & 3.75 & $216 /-$ \\
\hline 17 & - & $25.0 / 244$ & 8.96 & $120 /-$ \\
\hline
\end{tabular}

${ }^{\mathrm{a}}$ In NMP; ${ }^{\mathrm{b}}$ In $96 \% \mathrm{H}_{2} \mathrm{SO}_{4} ;{ }^{\mathrm{c}}$ By GPC in THF; ${ }^{\mathrm{d}}$ Insoluble in THF; ${ }^{\mathrm{e}}$ By DSC, $\mathrm{T}_{\mathrm{g}}=$ midpoint. 


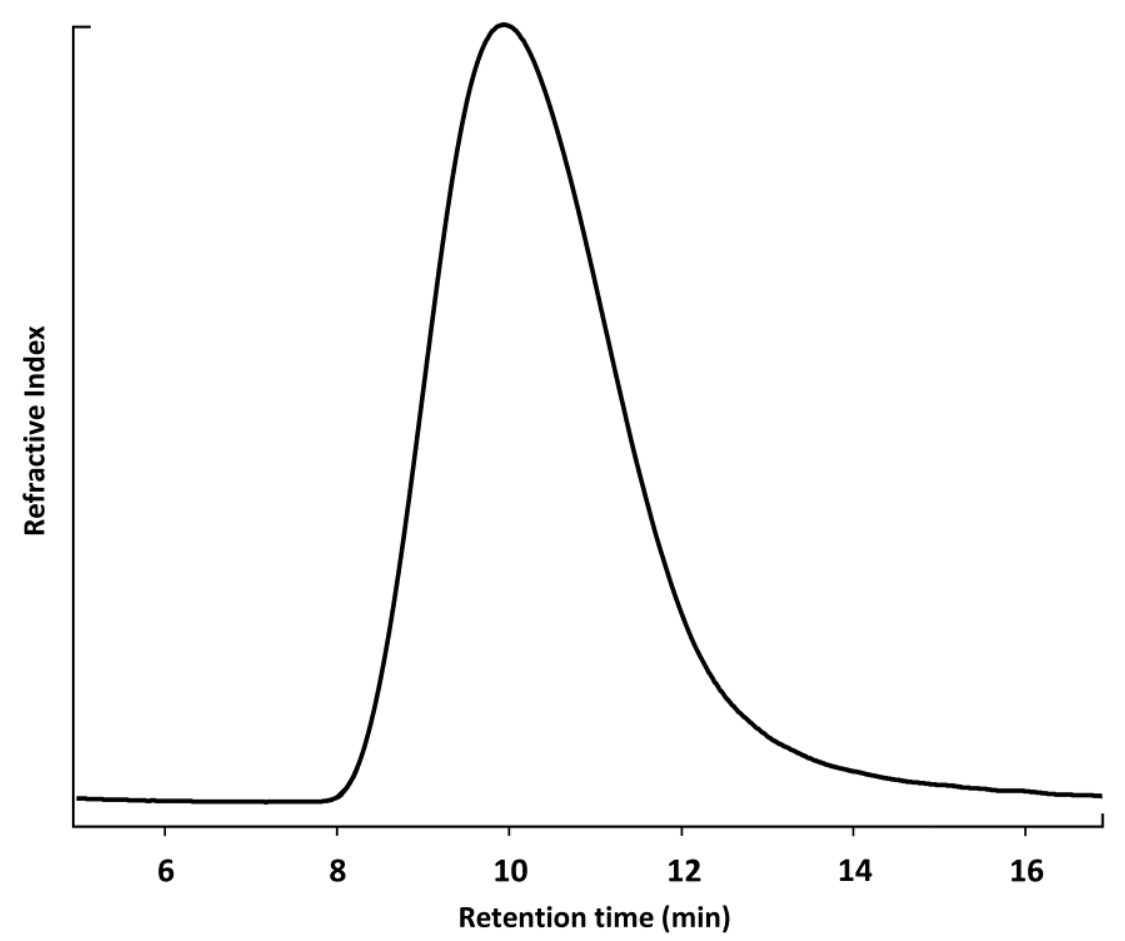

Figure 4. GPC curve for polymer 15 (THF as eluent). See Table 1.

The high polarity of the polyols (14-17) obtained in this work was demonstrated by their ready solubility in polar, protic solvents such as methanol, ethanol, 2-methoxyethanol and propan-2-ol, from which tough, coherent films (see SI) may be obtained on evaporation. However, the surfaces of such films are notably non-polar, with static water contact angles of ca. $90^{\circ}-$ comparable with literature values of $86^{\circ}$ for polystyrene, ${ }^{34}$ and $82^{\circ}$ for PEEK. ${ }^{35}$ Indeed, the contact angle for polyol $\mathbf{1 5}$ is essentially identical to that of its precursor polyketone $\mathbf{2}$ (see SI). This result demonstrates that the hydrophilic hydroxyl groups must be largely excluded from the polymer-air interface, ${ }^{36}$ leaving a higher proportion of the hydrophobic trifluoromethyl groups at the polymer surface than in the bulk. Indeed, preliminary XPS data for films of polyols $\mathbf{1 5}$ and 16 (spin-cast from 2-methoxyethanol), averaged over take-off angles of $25-60^{\circ}$, show significant surface-atom enrichment in the carbons associated with $\mathrm{CF}_{3}$ groups $\left(\mathrm{C}^{*}-\mathrm{CF}_{3}\right.$ and $\left.\mathrm{C}-\mathrm{C}^{*} \mathrm{~F}_{3}\right)$, and a 
corresponding depletion in aromatic carbon atoms. Table 2 gives XPS data for polymers $\mathbf{1 5}$ and 16, and the corresponding spectra are given as Supporting Information.

Table 2. XPS data (carbon 1s) for polymers $\mathbf{1 5}$ and $\mathbf{1 6}$

\begin{tabular}{|c|c|c|c|c|c|c|}
\hline Polymer & $\begin{array}{l}\text { Atom } \\
\text { type }\end{array}$ & 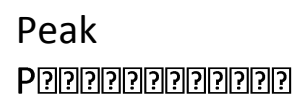 & $\begin{array}{l}\text { FWHM } \\
(\mathrm{eV})\end{array}$ & $\begin{array}{l}\text { Atom concn. } \\
\text { found }(\%)\end{array}$ & $\begin{array}{l}\text { Atom concn. } \\
\text { calcd. }(\%)\end{array}$ & $\begin{array}{l}\text { Atom concn. } \\
\text { excess }(\%)\end{array}$ \\
\hline \multirow{3}{*}{15} & Caromatic & 284.70 & 1.634 & 66.5 & 81.1 & -18.0 \\
\hline & ${ }^{*} \mathrm{C}-\mathrm{CF}_{3}$ & 286.75 & 1.634 & 15.6 & 8.1 & +92.6 \\
\hline & $\mathrm{C}-* \mathrm{CF}_{3}$ & 292.39 & 1.634 & 17.9 & 10.8 & +65.7 \\
\hline \multirow{3}{*}{16} & Caromatic & 284.45 & 1.643 & 74.0 & 85.8 & -13.8 \\
\hline & ${ }^{*} \mathrm{C}-\mathrm{CF}_{3}$ & 286.34 & 1.643 & 15.2 & 7.1 & +114 \\
\hline & $\mathrm{C}-{ }^{*} \mathrm{CF}_{3}$ & 291.95 & 1.643 & 10.8 & 7.1 & +52.1 \\
\hline
\end{tabular}

\section{Experimental Section}

\section{Materials and Instrumentation.}

Starting materials and solvents were purchased from Sigma-Aldrich or Fluorochem and were used as received, with the exception of anhydrous potassium carbonate which was heated at 100 ${ }^{\circ} \mathrm{C}$ under vacuum for $24 \mathrm{~h}$ before use, and tetrahydrofuran (THF), which was distilled under argon from sodium and benzophenone. Proton and ${ }^{13} \mathrm{C}$ NMR spectra were recorded on either a Bruker Nanobay 400 or a Bruker DPX 400 spectrometer, operating at $400 \mathrm{MHz}$ for ${ }^{1} \mathrm{H}$ NMR and $100 \mathrm{MHz}$ for ${ }^{13} \mathrm{C} \mathrm{NMR}$, respectively. Proton chemical shifts $(\delta)$ are reported in ppm relative to tetramethylsilane $(\delta 0.00 \mathrm{ppm})$ for $\mathrm{CDCl}_{3}$ or to the residual solvent peak for acetone- $d_{6}(\delta 2.05$ ppm) and DMSO- $d_{6}(\delta 2.50 \mathrm{ppm}) .{ }^{13} \mathrm{C}$ NMR chemical shifts are reported relative to chloroform $(\delta 77.0 \mathrm{ppm})$, acetone- $d_{6}(\delta 29.8 \mathrm{ppm})$ or DMSO- $d_{6}(\delta 39.5 \mathrm{ppm})$. Fourier transform infrared 
(FTIR) spectra were recorded on a Perkin Elmer 100 Spectrum FT-IR using a diamond ATR sampling accessory. Mass spectrometry was carried out using a ThermoFisher Scientific Orbitrap XL LCMS. The sample was introduced by liquid chromatography and sample ionisation was achieved by electrospray ionisation (ESI). Gel permeation chromatography (GPC) was conducted using an Agilent Technologies 1260 Infinity system calibrated with polystyrene standards. Samples were dissolved in analytical grade THF $\left(2 \mathrm{mg} \mathrm{mL}^{-1}\right)$ containing butylated hydroxytoluene (BHT) stabiliser and run using the same solvent as the mobile phase, eluting through two Agilent PLgel $5 \mu \mathrm{m}$ MIXED-D $300 \times 7.5 \mathrm{~mm}$ columns in series. Phase transitions (glass transitions, cold crystallizations and melting points) were identified by differential scanning calorimetry (DSC) under nitrogen, using a TA Instruments DSC 2920. Inherent viscosities $\left(\eta_{\text {inh }}\right)$ were measured at $25^{\circ} \mathrm{C}$ with $0.1 \% \mathrm{w} / \mathrm{v}$ polymer solutions in $N$-methyl-2pyrrolidone (NMP) or 96\% sulfuric acid $\left(\mathrm{H}_{2} \mathrm{SO}_{4}\right)$ using a Schott Instruments CT 52 viscometer. Polymer films for contact angle measurements were obtained by evaporation of polymer solutions in 2-methoxyethanol $\left(20 \mathrm{mg} \mathrm{mL}^{-1}\right)$ on glass microscope slides. X-ray photoelectron spectrscopy (XPS) was carried out in a custom-modified UHV chamber equipped with an unmonochromated Al-Ka (1486.6 eV) X-ray source, hemispherical electron energy analyser (run at $20 \mathrm{eV}$ pass energy) and a sample transfer stage. Polymer films for XPS were spin coated (40 s at $2400 \mathrm{rpm}$ ) from $20 \mu \mathrm{L}$ droplets of a $1 \% \mathrm{w} / \mathrm{v}$ polymer solution in a mixture of methanol $(80 \%)$ and propan-2-ol (20\%) onto gold-coated quartz microbalance crystals (Inficon 750-1000-G10).

Polymer syntheses. The synthesis of poly(ether ketone) $\mathbf{2}$ and its conversion to the poly(trifluoromethyl carbinol) $\mathbf{1 5}$ are described here to exemplify the chemistry. Full details of syntheses, instrumental analyses, and NMR assignments are given in the Supporting Information. 
Polymer 2: Potassium carbonate $(0.584 \mathrm{~g}, 4.23 \mathrm{mmol})$, NMP (13 mL), toluene (6 mL), 4,4'(hexafluoroisopropylidene)diphenol (1.345 g, $4.00 \mathrm{mmol}$ ) and 1,3-bis(4'-fluorobenzoyl)benzene $(1.421 \mathrm{~g}, 4.00 \mathrm{mmol})$ were introduced into a $50 \mathrm{~mL}$ round-bottom flask fitted with a stirrer, a Dean-Stark trap, a condenser and, a nitrogen inlet and outlet. The temperature was raised to 180 ${ }^{\circ} \mathrm{C}$ and water was removed by azeotropic distillation with toluene over two hours. After 6 hours, the mixture was cooled to room temperature and poured into methanol $(150 \mathrm{~mL})$. The precipitated polymer was filtered off, washed with water $(2 \times 60 \mathrm{~mL})$ and dried at $100{ }^{\circ} \mathrm{C}$ in vacuo. The polymer was then purified by two successive re-precipitations in methanol (150 $\mathrm{mL})$ from solution in the minimum amount of dichloromethane. After drying at $100{ }^{\circ} \mathrm{C}$ in vacuo, poly(ether ketone) 2 was obtained as a white solid $\left(1.98 \mathrm{~g}, 80 \%\right.$ yield). $T_{\mathrm{g}}$ (mid-point) $=158{ }^{\circ} \mathrm{C}$. $M_{\mathrm{n}}=20.4 \mathrm{kDa} ; M_{\mathrm{w}}=57.0 \mathrm{kDa} ; \bigoplus=2.80 ; \eta_{\text {inh }}=0.74 \mathrm{dL} \mathrm{g}^{-1}(\mathrm{NMP})$.

${ }^{1} \mathbf{H}$ NMR $\left(\mathrm{CDCl}_{3}, 400 \mathrm{MHz}\right): 7.09\left(\mathrm{H}_{\mathrm{b}}, \mathrm{d},{ }^{3} \mathrm{~J}_{\mathrm{bc}}=9 \mathrm{~Hz}\right), 7.12\left(\mathrm{H}_{\mathrm{h}}, \mathrm{d},{ }^{3} \mathrm{~J}_{\mathrm{hi}}=9 \mathrm{~Hz}\right), 7.23\left(\mathrm{H}_{\mathrm{c}}, \mathrm{d},{ }^{3} \mathrm{~J}_{\mathrm{cb}}=\right.$ $9 \mathrm{~Hz}), 7.62\left(\mathrm{H}_{\mathrm{o}}, \mathrm{t},{ }^{3} \mathrm{~J}_{\mathrm{om}}=8 \mathrm{~Hz}\right), 7.87\left(\mathrm{H}_{\mathrm{i}}, \mathrm{d},{ }^{3} \mathrm{~J}_{\mathrm{ih}}=9 \mathrm{~Hz}\right), 7.99\left(\mathrm{H}_{\mathrm{m}}, \mathrm{d},{ }^{3} \mathrm{~J}_{\mathrm{mo}}=8 \mathrm{~Hz}\right), 8.17\left(\mathrm{H}_{\mathrm{n}}, \mathrm{s}\right)$ ppm.

${ }^{13} \mathrm{C}$ NMR $\left(\mathrm{CDCl}_{3}, 100 \mathrm{MHz}\right): 118.3\left(\mathrm{C}_{\mathrm{h}}\right), 119.1\left(\mathrm{C}_{\mathrm{b}}\right), 128.5\left(\mathrm{C}_{\mathrm{o}}\right), 129.0\left(\mathrm{C}_{\mathrm{d}}\right), 130.8\left(\mathrm{C}_{\mathrm{n}}\right), 132.0$ $\left(\mathrm{C}_{\mathrm{c}}\right), 132.2\left(\mathrm{C}_{\mathrm{j}}\right), 132.6\left(\mathrm{C}_{\mathrm{i}}\right), 133.2\left(\mathrm{C}_{\mathrm{m}}\right), 138.0\left(\mathrm{C}_{1}\right), 156.4\left(\mathrm{C}_{\mathrm{a}}\right), 160.7\left(\mathrm{C}_{\mathrm{g}}\right), 194.5\left(\mathrm{C}_{\mathrm{k}}\right) \mathrm{ppm}$.

Polymer 11: To a stirred solution of poly(ether ketone) 2 (0.506 g, 0.816 mmols of repeat units) in dry THF $(20 \mathrm{~mL})$ were added, at $0{ }^{\circ} \mathrm{C}$ under nitrogen, trifluoromethyltrimethylsilane (5.20 $\mathrm{mL}, 35.1 \mathrm{mmol}$ ) and tetra- $n$-butylammonium fluoride (80 $\mathrm{mg}$ in $0.5 \mathrm{~mL}$ of THF, $0.310 \mathrm{mmol}$ ). The reaction mixture was stirred at $0{ }^{\circ} \mathrm{C}$ for $3 \mathrm{~h}$ and was then allowed to warm to $20^{\circ} \mathrm{C}$. After stirring for $18 \mathrm{~h}$ at $20^{\circ} \mathrm{C}$, the volatiles were removed in vacuo and the polymer was dissolved in the minimum amount of dichloromethane and precipitated in methanol (200 mL). After filtering 
off and drying at $100{ }^{\circ} \mathrm{C}$ in vacuo for $2 \mathrm{~h}$, the polymer was re-precipitated twice in methanol $(200 \mathrm{~mL})$ from solution in the minimum amount of dichloromethane. After drying at $100{ }^{\circ} \mathrm{C}$ in vacuo, the poly[trifluoromethyl(trimethylsilylether)] $\mathbf{1 1}$ was obtained as a white solid $(0.517 \mathrm{~g}$, $70 \%$ yield). $T_{\mathrm{g}}$ (mid-point) $=127^{\circ} \mathrm{C} . M_{\mathrm{n}}=59.0 \mathrm{kDa} ; M_{\mathrm{w}}=136 \mathrm{kDa} ; \oslash=2.31$.

${ }^{1} \mathbf{H}$ NMR $\left(\mathrm{CDCl}_{3}, 400 \mathrm{MHz}\right):-0.096\left(\mathrm{H}_{\mathrm{m}}, \mathrm{s}\right), 6.89-7.04\left(\mathrm{H}_{\mathrm{b}}+\mathrm{H}_{\mathrm{h}}, \mathrm{m}\right)$, 7.24-7.44 $\left(\mathrm{H}_{\mathrm{c}}+\mathrm{H}_{\mathrm{i}}+\mathrm{H}_{\mathrm{o}}+\mathrm{H}_{\mathrm{q}}\right.$, m), 7.52 and $7.63\left(\mathrm{H}_{\mathrm{p}}, \mathrm{s}\right) \mathrm{ppm}$.

${ }^{13} \mathrm{C}$ NMR $\left(\mathrm{CDCl}_{3}, 100 \mathrm{MHz}\right): 0\left(\mathrm{C}_{\mathrm{m}}\right), 80.2\left(\mathrm{C}_{1}\right), 116.7\left(\mathrm{C}_{\mathrm{b}}\right), 117.6\left(\mathrm{C}_{\mathrm{h}}\right), 126.3$-126.6 -126.8 $127.1\left(\mathrm{C}_{\mathrm{p}}+\mathrm{C}_{\mathrm{o}}+\mathrm{C}_{\mathrm{q}}\right), 126.7\left(\mathrm{C}_{\mathrm{d}}\right), 128.7\left(\mathrm{C}_{\mathrm{i}}\right), 130.6\left(\mathrm{C}_{\mathrm{c}}\right), 135.1\left(\mathrm{C}_{\mathrm{j}}\right), 139.5\left(\mathrm{C}_{\mathrm{n}}\right), 154.9\left(\mathrm{C}_{\mathrm{g}}\right), 156.4$ $\left(\mathrm{C}_{\mathrm{a}}\right) \mathrm{ppm}$.

Polymer 15: To a stirred solution of the silyl poly(ether) 11 (1.53 g, 1.69 mmols of repeat units) in dry THF $(85 \mathrm{~mL})$ was added tetrabutylammonium fluoride $(9.50 \mathrm{~g}$ in $15 \mathrm{~mL}$ of THF, 36.3 mmol) under nitrogen. After $24 \mathrm{~h}$ the volatiles were removed in vacuo and the polymer was dissolved in the minimum amount of acetone and precipitated in water $(300 \mathrm{~mL})$ and was filtered off and dried under vacuum at $100{ }^{\circ} \mathrm{C}$. It was then was dissolved in the minimum amount of acetone and re-precipitated in water $(300 \mathrm{~mL})$. After drying at $100{ }^{\circ} \mathrm{C}$ in vacuo over 2 hours, the polymer was re-precipitated twice in water $(300 \mathrm{~mL})$, from solution in the minimum amount of acetone. After drying at $100{ }^{\circ} \mathrm{C}$ in vacuo, the poly(trifluoromethyl)carbinol $\mathbf{1 5}$ was obtained as a pale brown solid $(1.01 \mathrm{~g}, 79 \%$ yield $) . T_{\mathrm{g}}($ mid-point $)=143{ }^{\circ} \mathrm{C} . M_{\mathrm{n}}=420 \mathrm{kDa} ; M_{\mathrm{w}}=1,640 \mathrm{kDa}$; $Ð=3.90$.

Table 3. Solubility characteristics of poly(trifluoromethyl)carbinol $\mathbf{1 5}$

\begin{tabular}{|c|cccccccc|}
\hline Solvent & Acetone & THF & $\mathrm{CHCl}_{3}$ & $\mathrm{CH}_{2} \mathrm{Cl}_{2}$ & $\mathrm{MEK}$ & $\mathrm{MeOH}$ & $\mathrm{EtOH}$ & i-PrOH \\
\hline Solubility at $20^{\circ} \mathrm{C}$ & Yes & Yes & Yes & Yes & Yes & Yes & Yes & Yes \\
\hline
\end{tabular}


${ }^{1} \mathbf{H}$ NMR $\left(\mathrm{CDCl}_{3}, 400 \mathrm{MHz}\right): 2.96\left(\mathrm{H}_{\mathrm{m}}, \mathrm{s}\right), 6.94\left(\mathrm{H}_{\mathrm{b}}, \mathrm{d},{ }^{3} \mathrm{~J}_{\mathrm{bc}}=8 \mathrm{~Hz}\right), 6.98\left(\mathrm{H}_{\mathrm{h}}, \mathrm{d},{ }^{3} \mathrm{~J}_{\mathrm{hi}}=8 \mathrm{~Hz}\right)$, $7.33\left(\mathrm{H}_{\mathrm{c}}+\mathrm{H}_{\mathrm{q}}, \mathrm{m},{ }^{3} \mathrm{~J}_{\mathrm{cb}}=8 \mathrm{~Hz}\right), 7.41\left(\mathrm{H}_{\mathrm{i}}, \mathrm{m},{ }^{3} \mathrm{~J}_{\mathrm{ih}}=8 \mathrm{~Hz}\right), 7.46\left(\mathrm{H}_{\mathrm{o}}, \mathrm{m},{ }^{3} \mathrm{~J}_{\mathrm{oq}}=7 \mathrm{~Hz}\right), 7.67$ and 7.70 $\left(\mathrm{H}_{\mathrm{p}}, \mathrm{s}\right) \mathrm{ppm}$.

${ }^{13} \mathrm{C}$ NMR $\left(\mathrm{CDCl}_{3}, 100 \mathrm{MHz}\right): 79.3\left(\mathrm{C}_{1}\right), 118.1\left(\mathrm{C}_{\mathrm{b}}\right), 119.0\left(\mathrm{C}_{\mathrm{h}}\right), 126.5\left(\mathrm{C}_{\mathrm{p}}\right), 127.9\left(\mathrm{C}_{\mathrm{o}}\right)$, 128.1( $\left.\mathrm{C}_{\mathrm{d}}\right), 128.3\left(\mathrm{C}_{\mathrm{q}}\right), 129.2\left(\mathrm{C}_{\mathrm{i}}\right), 131.8\left(\mathrm{C}_{\mathrm{c}}\right), 134.5\left(\mathrm{C}_{\mathrm{j}}\right), 139.3\left(\mathrm{C}_{\mathrm{n}}\right), 156.5\left(\mathrm{C}_{\mathrm{g}}\right), 157.3\left(\mathrm{C}_{\mathrm{a}}\right) \mathrm{ppm}$.

\section{Conclusions}

Fluoride-catalyzed reactions of trimethyl(trifluoromethyl)silane with aromatic poly(ether ketone)s afford soluble, amorphous polymers in which the carbon-silicon bond of $\mathrm{CF}_{3} \mathrm{SiMe}_{3}$ has added across the carbonyl-oxygen double bond of each carbonyl group. Subsequent desilylation with excess fluoride ion yields poly(arylene-trifluoromethylcarbinol)s that are readily soluble in high-polarity solvents such as methanol, ethanol, and 2-methoxyethanol, to give solutions from which tough, coherent films may be cast by evaporation in air. Despite the evident polarity of the bulk polymers, the surfaces of these cast films are relatively non-polar, with water contact angles comparable to that of polystyrene.

\section{Supporting Information}

Methods and materials, full synthetic details, and characterisation data (PDF) for monomers 8 and 9 and polymers 1-4, 10-13 and 14-17. The Supporting Information is available free of charge on the ACS Publications website. 


\section{Author Information}

\section{Corresponding author}

*(H.M.C.) E-mail: h.m.colquhoun@rdg.ac.uk

ORCID

Howard M. Colquhoun: 0000-0002-3725-4085

\section{Notes}

The authors declare no competing financial interest.

\section{Acknowledgements}

We are grateful to Tahkur Singh Babra for assistance with tensile testing. We thank the Engineering and Physical Sciences Research Council of the UK (EPSRC) for a Platform Grant (EP/L020599/1) and a research grant (GR/K49560/02) in support of this work.

\section{References}

1. Hergenrother, P. M. The use, design, synthesis, and properties of high performance/ high temperature polymers: an overview. High Perf. Polym. 2003, 15, 3-45.

2. Liu, L.; Yan, F.; Gai, F.; Xiao, L.; Shang, L.; Li, M.; Ao, Y. In situ determination of mechanical properties for poly(ether ether ketone) film under extreme conditions. RSC Adv. 2017, 7, 8670-8676.

3. Glover, L. C.; Magay, D. Stilan 1000 - A versatile high performance polymer for hostile environments. Tech. Papers - Soc. Plast. Eng. 1976, 22, 148-149. 
4. Monich, P.; Henriques, B.; de Oliveira, A. P. N.; Souza, J. C. M.; Fredel, M. C. Mechanical and biological behavior of biomedical PEEK matrix composites: A focused review. Mater. Lett. 2016, 185, 593-597.

5. Liang, Q.; Wu, X. Research status of carbon fiber-reinforced PEEK composites. Adv. Mater. Res. 2014, 834-836, 225-228.

6. Shukla, D.; Negi, Y. S.; Uppadhyaya, J. S.; Kumar, V. Synthesis and modification of poly(ether ether ketone) and their properties: a review. Polym. Rev. 2012, 52, 189-228.

7. Shibuya, N.; Porter, R. S. Kinetics of PEEK sulfonation in concentrated sulfuric acid. Macromolecules 1992, 25, 6495-6499.

8. Colquhoun, H. M.; Taylor, T. M. C. Membranes. Eur. Pat. 0382356 B1, 1995, to North West Water Group plc.

9. Karcha, R. J.; Porter R. S. Preparation and characterization of nitrated poly(aryl ether ketone). J. Macromol. Sci., Part A: Pure Appl. Chem. 1995, 32, 957-967.

10. Conceição, T. F.; Bertolino, J.R.; Barra, G. M. O, Mireski, S. L.; Joussefa, A. C.; Pires, A. T. N. Preparation and characterization of poly(ether ether ketone) derivatives. J. Braz. Chem. Soc. 2008, 19, 111-116.

11. Ben-Haida, A.; Colquhoun, H. M.; Hodge, P.; Lewis, D. F. Reduction of carbonyl groups in aromatic polyketones: synthesis and characterization of methylene-bridged polyarylethers and -thioethers. Polymer 1999, 40, 5173-5182.

12. Díez-Pascual, A. M.; Martínez, G.; Gómez, M. A. Synthesis and characterization of poly(ether ether ketone) derivatives obtained by carbonyl reduction. Macromolecules 2009, 42, 6885-6892.

13. Manolakis, I.; Cross, P.; Colquhoun, H. M. Direct Iminization of PEEK. Macromolecules 2011, 44, 7864-7867. 
14. Colquhoun, H. M.; Paoloni, F. P. V.; Drew, M. G. B.; Hodge, P. Dithioacetalisation of PEEK: a general technique for the solubilisation and characterisation of semi-crystalline aromatic polyketones. Chem. Commun. 2007, 3365-3367.

15. Colquhoun, H. M.; Hodge, P.; Paoloni, F. P. V.; McGrail, P. T.; Cross, P. Reversible, nondegradative conversion of crystalline aromatic poly(ether ketone)s into organosoluble poly(ether dithioketal)s. Macromolecules 2009, 42, 1955-1963.

16. Noiset, O.; Henneuse, C.; Schneider, Y. J.; Marchand-Brynaert, J. Surface reduction of poly(aryl ether ether ketone) film: UV spectrophotometric, ${ }^{3} \mathrm{H}$ radiochemical, and X-ray photoelectron spectroscopic assays of the hydroxyl functions. Macromolecules 1997, 30, $540-548$.

17. Fristrup, C. J.; Jankova, K.; Hvilsted, S. Hydrophilization of poly(ether ether ketone) films by surface-initiated atom transfer radical polymerization. Polym. Chem. 2010, 1, $1696-1701$.

18. Chen,M.; Ouyang, L.; Lu, T.; Wang, H.; Meng, F.; Yang, Y.; Ning, C.; Ma,J.; Liu, X. Enhanced bioactivity and bacteriostasis of surface fluorinated polyetheretherketone. ACS Appl. Mater. Interfaces 2017, 9, 16825-16834.

19. Ruppert, I.; Schlich, K.; Volbach, W. Die ersten $\mathrm{CF}_{3}$-substituierten organyl(chlor)silane. Tetrahedron Lett. 1984, 25, 2195-2198.

20. Prakash, G. K. S.; Krishnamurti, R.; Olah, G.A. Fluoride-induced trifluoromethylation of carbonyl compounds with trifluoromethyltrimethylsilane (TMS-CF 3$)$. A trifluoromethide equivalent. J. Am. Chem. Soc. 1989, 111, 393-395.

21. Prakash, G. K. S.; Yudin, A. K. Perfluoroalkylation with organosilicon reagents. Chem. Rev. 1997, 97, 757-786.

22. Hiraoa, A.; Sugiyama, K.; Yokoyama, H. Precise synthesis and surface structures of architectural per- and semifluorinated polymers with well-defined structures. Prog. Polym. Sci. 2007, 32, 1393-1438. 
23. Lüning, J.; Stöhr, J.; Song, K. Y.; Hawker, C. J.; Iodice, P.; Nguyen, C. V.; Yoon, D. Y. Correlation of surface and bulk order in low surface energy polymers. Macromolecules 2001, 34, 1128-1130.

24. Borkar, S.; Jankova, K.; Siesler, H. W.; Hvilsted, S. New highly fluorinated styrenebased materials with low surface energy prepared by ATRP. Macromolecules 2004, 37, 788-794.

25. Discekici, E. H.; Anastasaki, A.; Kaminker, R.; Willenbacher, J.; Truong, N. P.; Fleischmann, C.; Oschmann, B.; Lunn, D. J.; de Alaniz, J. R.; Davis, T. P.; Bates, C. M.; Hawker, C. J. Light-mediated atom transfer radical polymerization of semifluorinated (meth)acrylates: facile access to functional materials. J. Am. Chem. Soc. 2017, 139, 5939-5945.

26. Ishizone, T.; Sugiyama, K.; Sakano, Y.; Mori, H.; Hirao A.; Nakahama, S. Anionic polymerizations of perfluoroalkyl methacrylates and synthesis of well-defined $\mathrm{ABC}$ triblock copolymers of methacrylates containing hydrophilic, hydrophobic, and perfluoroalkyl groups. Polym. J. 1999, 31, 983-988.

27. Hunt Jr, M. O.; Belu, A. M.; Linton, R.W.; DeSimone, J. M. End-functionalized polymers. 1. Synthesis and characterization of perfluoroalkyl-terminated polymers via chorosilane derivatives. Macromolecules 1993, 26, 4854-4859.

28. Sugiyama, K.; Hirao, A.; Nakahama, S. Synthesis of end-functionalized polymer by means of living anionic polymerization, 7: reaction of anionic living polymers with perfluoroalkyl halides. Macromol. Chem. Phys. 1996, 197, 3149-3165.

29. McHugh, M. A.; Park, I-H.; Reisinger, J. J.; Ren, Y.; Lodge, T. P.; Hillmyer, M. A. Solubility of $\mathrm{CF}_{2}$-modified polybutadiene and polyisoprene in supercritical carbon dioxide. Macromolecules 2002, 35, 4653-4657.

30. Hillmyer, M. A.; Schmuhl, N. W.; Lodge, T. P. Fluorinated amphiphilic block copolymers: combining anionic polymerization and selective polymer modification. Macromol. Symp. 2004, 215, 51-56. 
31. Staniland, P. A., "Poly(ether ketone)s". In Comprensive Polymer Science; Allen, G.; Bevington, J. C., Ed. Pergamon: Oxford, 1989; Vol. 5, 483-497.

32. Bryant, R. G.; Jensen, B. J.; Hergenrother, P. M. Synthesis and properties of phenylethynyl-terminated arylene ethers. Polym. Prepr. (Am. Chem. Soc., Div. Polym. Chem.) 1992, 33, 910-911.

33. Gardner, K. H.; Hsiao, B. S.; Matheson, R. R.; Wood, B. A. Structure, crystallization and morphology of poly(aryl ether ketone ketone). Polymer 1992, 33, 2483-2495.

34. Li, Y.; Pham, J. Q.; Johnston, K. P.; Green, P. F. Contact angle of water on polystyrene thin films: effects of $\mathrm{CO}_{2}$ environment and film thickness. Langmuir 2007, 23, 97859793.

35. Investigation of Plasma Treatment on Micro-Injection Moulded Microneedle for Drug Delivery. Nair, K.; Whiteside, B.; Grant, C.; Patel, R.; Tuinea-Bobe, C.; Norris, K.; Paradkar, A. Pharmacetics, 2015, 7, 471-485.

36. Yasuda, H.; Sharma, A. K.; Yasuda, T. Effect of orientation and mobility of polymer molecules at surfaces on contact angle and its hysteresis. J. Polym. Sci. Part B. Polym. Phys. 1981, 19, 1285-1291. 


\section{Trifluoromethylation of carbonyl groups in aromatic poly(ether ketone)s: formation of strongly polar yet surface-hydrophobic poly(arylenenecarbinol)s}

Flavien Leroux, Roger A. Bennett, David F. Lewis and Howard M. Colquhoun*

Department of Chemistry, University of Reading, Whiteknights, Reading, RG6 6AD, UK

TOC Graphic

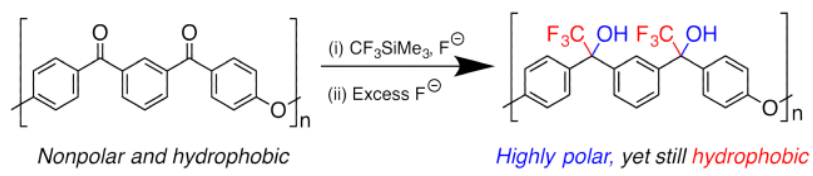

